\title{
EFEKTIVITAS MODEL PEMBELAJARAN LEARNING CYCLE TERHADAP KEMAMPUAN MENULIS TEKS DESKRIPSI SISWA KELAS VII SMP NEGERI 2 NAINGGOLAN
}

\author{
${ }^{1}$ Mariana Siringoringo, ${ }^{2}$ Inayah Hanum \\ ${ }^{1,2}$ Prodi Pendidikan Bahasa dan Sastra Indonesia, Universitas Negeri Medan \\ Email: ${ }^{1}$ (siringomary@gmail.com.com) ${ }^{2}$ (Inayahhanumlubis@ gmail.com)
}

\begin{abstract}
ABSTRAK
Tujuan penelitian ini adalah untuk mengetahui efektivitas model pembelajaran Learning Cycle terhadap kemampuan menulis teks deskripsi siswa kelas VII SMP Negeri 2 Nainggolan Tahun Pembelajaran 2019/2020. Pengambilan sampel dilakukan secara acak dan didapat kelas VII-1(kelas eksperimen) dan kelas VII-3 (kelas kontrol) sebagai sampel dalam penelitian ini dengan jumlah kelas masing-masing 32 orang. Metode yang digunakan dalam penelitian ini adalah metode eksperimen dengan desain penelitian two group post test design. Data yang diperoleh menunjukkan hasil belajar menulis teks deskripsi saat menggunakan model pembelajaran Konvensional (kelas kontrol) sebanyak 65,2 berada pada kategori cukup dan saat menggunakan model pembelajaran Learning Cycle (kelas eksperimen) sebanyak 77,18 berada pada kategori baik. Pengujian hipotesis dengan menggunakan uji " $\mathrm{t}$ " diperoleh nilai $\mathrm{t}_{0}$ $=3,576$. Selanjutnya dikonsultasikan dengan tabel $\mathrm{t}$ pada taraf signifikan $5 \%$ atau $\alpha=0,05$ dengan $\mathrm{df}=\mathrm{N}-1 . \mathrm{df}=32-1=31$, maka diperoleh $\mathrm{t}_{\text {tabel }}$ pada taraf signifikansi $5 \%=2,03$. Nilai t0>ttabel atau 3,576>2,03. Sehingga, hipotes is nihil (Ho) ditolak dan hipotesis alternatif (Ha) diterima. Hal ini membuktikan model pembelajaran Learning Cyle efektif digunakan terhadap kemampuan menulis teks deskripsi siswa kelas VII SMP Negeri 2 Nainggolan tahun pembelajaran 2019/2020.
\end{abstract}

Kata Kunci: Model pembelajaran Learning Cycle, menulis teks deskripsi

\section{A. PENDAHULUAN}

Pelajaran Bahasa Indonesia mencakup kemampuan berbahasa yang meliputi empat aspek yaitu menyimak, berbicara, membaca, dan menulis. Keempat aspek tersebut merupakan pencapaian yang saling berhubungan. Ditinjau dari sisi pelaku kegiatan berbahasa menyimak dan membaca merupakan keterampilan berbahasa yang pasif. Dalam kegiatan membaca dan menyimak 
hanya membutuhkan pemahaman untuk mengerti dan memahami isi tulisan atau pesan-pesan yang terdapat di dalam bacaan atau pembicaraan orang lain, sedangkan kegiatan menulis dan berbicara merupakan jenis kegiatan berbahasa yang aktif. Hal ini dikarenakan penulis dan pembicara harus aktif mengeks presikan pemikiran/gagasan yang terdapat di dalam pikiran ke dalam bentuk tulisan sehingga dapat dipahami oleh pembaca. Menulis merupakan kegiatan yang aktif dan kreatif karena kegiatan yang dihasilkan melalui tulisan itu adalah pencerminan ide, gagasan pikiran seseorang yang dapat dipahami atau dimengerti oleh orang lain yang disampaikan melalui tulisan.

Akhadiah (1993: 64) mengemukakan bahwa keterampilan menulis sangat kompleks karena menuntut siswa untuk menguasai komponen - komponen di dalamnya, misalnya penggunaan ejaan yang benar, pemilihan kosakata yang tepat, penggunaan kalimat efektif, dan penyus unan paragraf yang baik. Sejalan dengan penelitian Permanasari dengan judul 'Kemampuan Menulis Teks Deskripsi Siswa Kelas VII SMP Negeri 1 Sumber Jaya Lampung Barat” mengatakan menulis merupakan kemampuan paling sulit dimana membutuhkan kemampuan kemampuan lain untuk mencapai tingkat mahir. Untuk menulis secara sistematis, harus menjadi pendengar, pembicara dan pembaca yang juga siste matis.

Menurut Tarigan (2008: 3) menulis merupakan salah satu keterampilan berbahasa yang dipergunakan untuk berkomunukasi dengan orang lain. Menulis merupakan suatu kegiatan produktif dan ekspresif. Keterampilan menulis ini tidak datang secara otomatis melainkan melakukan latihan dan praktek yang banyak dan teratur.

Sayuti (2009: 3) mengungkapkan kesan negatif terhadap aktivitas menulis itu karena menulis dianggap aktivitas yang sulit dan rumit. Sayuti (2009: 18) mengatakan semakin matang ide yang muncul di kepala, semakin bagus juga kualitas tulisan yang dihasilkan.

Berdasarkan kurikulum 2013 kelas VII SMP untuk mata pelajaran bahasa Indonesia, salah satu kompetensi keterampilan menulis yang harus dimiliki siswa adalah keterampilan menulis teks deskripsi. Seseorang dikatakan terampil menulis teks apabila orang tersebut mampu mengutarakan ide yang ada dibenaknya 
melalui media tulis serta berpedoman dengan struktur dan ciri kebahasaan yang sudah terdapat dalam masing-masing teks. Hal tersebut juga terdapat dalam silabus kurikulum 2013 tingkat SMP kelas VII. Pembelajaran menulis teks deskripsi terdapat pada kompetensi dasar yaitu KD 4.2 menyajikan data, gagasan, kesan dalam bentuk teks deskripsi tentang bentuk sekolah, tempat wisata, te mpat bersejarah dan atau suasana pentas seni daerah) secara lisan dan tulis.

Mengacu kepada pemikiran di atas, jelaslah bahwa menulis bukan hanya sekedar menuliskan apa yang diucapkan, tetapi merupakan suatu kegiatan yang terorganisir sedemikian rupa, sehingga terjadi suatu tindak komunikasi antara penulis dengan pembaca. Salah satu komunikasi tulis yang dapat digunakan untuk menya mpaikan maksud pada pembaca atau orang lain yaitu teks deskripsi.

Berdasarkan pendapat tersebut kegiatan menulis teks deskripsi sangat penting diajarkan kepada siswa di sekolah agar siswa memiliki keterampilan menulis yang baik dan benar serta sebagai bekal dalam kehidupan bermasyarakat. Kegiatan menulis merupakan kegiatan yang sering dilakukan siswa setiap hari, tetapi masih banyak kesalahan pada tulisan siswa dalam menulis teks deskripsi di SMP N 2 Nainggolan pada kelas VII. Kesalahan yang dibuat siswa pada umumnya adalah, (1) kurang tepat dalam menggunakan kata (diksi), (2) kurang terampil dalam menyusun kalimat yang efektif, (3) kurang jelas dalam menyampaikan ide, (4) kurang tepat dalam penggunaan ejaan, (5) kurang terampil dalam menyusun kepaduan dan kesesuaian.

Hal itu terbukti ketika dilakukan wawancara dengan guru. Ada dua faktor penyebab siswa mas ih kesulitan menulis te ks deskripsi, yaitu faktor dari siswa dan faktor dari guru. Adapun faktor penyebab dari siswa yaitu kurangnya minat siswa terhadap pelajaran Bahasa Indonesia sehingga indikator tidak dapat dicapai siswa. Kemudian siswa juga tidak bersemangat ketika mengikuti pembelajaran, sehingga suasana kelas kurang produktif. Sedangkan faktor penyebab dari guru yaitu model pembelajaran yang digunakan model pembelajaran konvensional sehingga pembelajaran kurang menarik perhatian siswa dan mudah bosan dengan pembelajaran dan hasil belajar kurang maksimal. Model belajar yang digunakan selama ini masih bersifat satu arah artinya guru lebih aktif mentransfer 
pengetahuan hasil pikirannya kepada siswa, sedangkan siswa pasif dan menerima apa yang disampaikan guru.

Guru pada umumnya hanya menerangkan hal-hal yang berhubungan dengan teori menulis teks deskipsi saja, misalnya pengertian teks deskripsi, dan ciri-ciri teks deskripsi. Hal ini mengakibatkan pembelajaran menulis teks deskripsi di ke las kurang baik.

Hasil observasi dan wawancara yang dilakukan penulis terhadap guru bahasa Indonesia yang mengajar di SMP N 2 Nainggolan menyatakan bahwa secara umum siswa kurang mampu menulis karena mereka kurang memiliki ekspresi gagasan yang berkesinambungan dan belum mempunyai urutan yang logis dengan menggunakan kosa kata dan kaidah bahasa yang digunakan sehingga nilai keterampilan menulis teks deskripsi siswa kelas VII SMP N 2 Nainggolan masih tergolong rendah. Hal ini dapat dilihat dari nilai nilai rata-rata kelas untuk mata pelajaran menulis teks deskripsi yang tergolong rendah hanya mencapai nilai 68 sedangkan nilai KKM yang ditentukan oleh sekolah adalah 70. Hanya 45 $\%$ yang dapat memenuhi target yang telah ditetapkan. Kemampuan dalam menulis teks deskripsi masih belum optimal sehingga perlu dilakukan upaya peningkatan teks deskripsi. Hal tersebut dibuktikan oleh penelitian terdahulu penelitian yang dilakukan oleh Erwansyah (2014) yang berjudul “Kemampuan Menulis Paragraf Deskripsi Siswa Kelas VII C SMP Negeri 17 Batanghari.” Hasil dari penelitian ini mengatakan bahwa kemampuan siswa menulis teks deskripsi masih kurang. Hal ini terbukti dengan diperolehnya rata-rata nilai akhir yaitu 53,26, nilai tersebut dilihat dari tabel interval nilai yang berada pada interval 40-54\%. Interval nilai tersebut menurut tabel konversi nilai itu berkualitas kurang mampu. Selain itu penelitian yang pernah dilakukan oleh Siburian (2010:51) yang berjudul : Efektivitas Teknik Clustering 'Pengelompokan' terhadap Peningkatan Kemampuan Menulis Karangan Deskripsi Siswa Kelas X SMA Negeri 1 Lintongnihuta Tahun Pembelajaran 2009/2010" dengan kesimpulan rata-rata menulis karangan deskripsi siswa berada pada kategori rendah yaitu 64,15. 
Sebagaimana keterangan yang diberikan guru bahasa Indonesia di SMP N 2 Nainggolan rendahnya kualitas pembelajaran menulis teks deskripsi disebabkan oleh beberapa faktor yaitu: (1) siswa kesulitan dalam menuangkakan idenya kedalam bentuk tulisan yang utuh, (2) kurangnya kemampuan siswa dalam menentukan topik menulis teks deskripsi, (3) guru kesulitan dalam membangkitkan minat belajar siswa tentang menulis teks deskripsi, (4) siswa kurang mampu mengaitkan materi dengan kehidupan sehari-hari.

Berdasarkan uraian di atas, peneliti mengemukakan salah satu solusi untuk merangsang siswa agar dapat menulis teks deskripsi dengan menggunakan model pembe lajaran yang menarik dan membuat siswa lebih berperan aktif da lam proses pembelajaran. Adapun model yang digunakan dalam meningkatkan kemampuan menulis teks deskripsi adalah model pembelajaran learning cycle (pembelajaran siklus).

\section{B. KAJIAN TEORI}

Teks deskripsi adalah jenis teks yang menggambarkan sesuatu dengan jelas dan terperinci. Tujuan dari menulis teks deskripsi adalah meggambarkan atau melukiskan pengalaman, pedengaran, perabaan, peciuman,dan perasaan situasi atau masalah. Penginderaan terhadap suatu peristiwa akan melahirkan suatu gambaran mengenai peristiwa itu seperti yang dilihat, didengar, diraba, dicium, atau dirasakan. Demikian juga penginderaan terhadap suatu keadaan, situasi atau masalah akan melahirkan gambaran atau lukisan yang bertumpu pada penglihatan, pendengaran, perabaan, penciuman atau perasaan. Dalam suatu teks deskripsi penulis berusaha memindahkan kesan, hasil pengamatan dan perasaannya kepada pembaca dengan menyampaikan sifat dan semua perincian yang dapat ditemukan pada bentuk tersebut.

Menurut Wena (2009:170), "Pembelajaran siklus (learning cycle) merupakan rangkaian tahap-tahap kegiatan yang diorganisasikan sedemikian rupa sehingga pembelajar dapat menguasai potensi-potensi yang harus dicapai dalam pembelajaran dengan jalan berperan aktif. Pada model pembelajaran siklus (learning cycle) melalui tahap-tahap yang dirancang siswa diarahkan untuk aktif 
mencari informasi untuk membangun pemahaman mereka terhadap materi serta dapat menyampaikan pendapatnya baik secara lisan maupun tulisan mengenai materi yang dipelajari. Pendapat yang disampaikan haruslah didasarkan pada bukti-bukti yang telah dianalis is terlebih dahulu untuk meyakinkan orang lain. Model ini sangat cocok digunakan untuk meningkatkan kemampuan menulis teks deskripsi karena dalam menulis teks deskripsi seseorang harus aktif dan kreatif mengumpulkan informasi dan mampu menyampaikan idenya mengenai suatu hal serta melampirkan suatu bukti atau fakta yang mendukung ga gasan atau pendapat.

\section{METODE PENELITIAN}

Metode yang digunakan dalam penelitian ini yaitu metode eksperimen dengan desain two group post test design. Maka, dalam penelitian ini peneliti menggunakan metode eksperimen yang melibatkan dua kelas yang diberikan perlakuan yang berbeda. Pada kelas eksperimen digunakan model pembelajaran Learning Cycle dan pada kelas kontrol digunakan model konvensional.

\section{HASIL PENELITIAN DAN PEMBAHASAN}

Berikut adalah kecenderungan kelas kontrol dalam penelitian ini.

Tabel 1

Identifikasi Kecenderungan Kelas Kontrol

\begin{tabular}{c|c|c|c}
\hline Rentang & F. Absolut & F. Relatif & Kategori \\
\hline $85-100$ & 0 & $0 \%$ & Baik Sekali \\
$70-84$ & 10 & $31,25 \%$ & Baik \\
$55-69$ & 13 & $40,62 \%$ & Cukup \\
$40-54$ & 6 & $18,75 \%$ & Kurang \\
$0-39$ & 3 & $9,37 \%$ & Kurang Sekali \\
\hline & 32 & $100 \%$ & \\
\hline
\end{tabular}

kemampuan menulis teks deskripsi dengan menggunakan model konvensional termasuk kategori baik sekali tidak ada, kategori baik sebanyak 10 orang atau $31,25 \%$, kategori cukup sebanyak 13 orang atau 40,62\%, kategori kurang 
sebanyak 6 orang atau 18,75\% dan kategori kurang sekali sebanyak 3 orang atau $9,37 \%$.

Tabel 2

Identifikasi Kecenderungan Kelas Eksperimen

\begin{tabular}{c|c|c|c}
\hline Rentang & F. Absolut & F. Re latif & Kategori \\
\hline $85-100$ & 2 & $6,25 \%$ & Baik Sekali \\
$70-84$ & 18 & $56,25 \%$ & Baik \\
$55-69$ & 11 & $34,375 \%$ & Cukup \\
$40-54$ & 1 & $3,125 \%$ & Kurang \\
$0-39$ & 0 & $0 \%$ & Kurang Sekali \\
\hline \multicolumn{2}{c}{ Dari tabel di atas dapat diketahui bahwa kelas eksperimen yakni }
\end{tabular}

peningkatan kemampuan menulis teks deskripsi dengan menggunakan model learning cycle termasuk kategori baik sekali sebanyak 2 orang atau 6,25\%, kategori baik sebanyak 18 orang atau 56,25\%, kategori cukup sebanyak 11 orang atau $34,375 \%$, dan kategori kurang sebanyak 1 orang atau 3,125\%.

Berdasarkan aspek penilaian dalam menulis teks deskripsi yang telah dibahas, hasil belajar siswa dalam menulis teks deskripsi di kelas kontrol termasuk ke dalam kategori cukup karena pada rata-rata 65,2, dengan standar deviasi 15,48, dan standar error 2,78. Adapun frekuensi penilaian dimana kategori baik sekali sebanyak 0 orang atau $0 \%$, kategori baik sebanyak 10 orang atau $31,25 \%$, kategori cukup sebanyak 13 orang atau 40,62\%, kategori kurang sebanyak 6 orang atau 18,75\% dan kategori sangat kurang sebanyak 3 orang atau $9,37 \%$.

Berdasarkan aspek penilaian dalam menulis teks deskripsi yang telah dibahas sebelumnya, hasil belajar siswa dalam menulis teks deskripsi termasuk dalam kategori baik karena pada rata-rata 77,18, standar deviasi 10,84, dan standar error 1,88. Berdasarkan frekuensi penilaian, jumlah siswa yang masuk dalam kategori baik sekali yaitu sebanyak 2 orang atau $6,25 \%$, kategori baik 
sebanyak 18 orang atau 56,25\%, kategori cukup sebanyak 11 orang atau 34,375\% dan kategori kurang sebanyak 1 orang atau 3,125\%.

Sampel masing-masing kelas (kontrol dan eks perimen) adalah 30 orang. Berdasarkan perolehan data dapat dilihat peningkatan dan penurunan kualitas siswa dari dua kelas dengan dua perlakuan. Dalam sebagian besar indikator, terlihat bahwa siswa dalam kelas eksperimen lebih unggul daripada kelas kontrol.

Pengujian hipotesis menunjukkan bahwa $t_{o}$ yang diperoleh lebih besar dari $t_{\text {tabel }}$ yaitu 3,576 $>2,03$. Karena $t_{o}$ yang diperoleh lebih besar dari $t_{\text {tab el }}$, maka dapat dinyatakan $H_{o}$ ditolak dan $H_{a}$ diterima. Hal ini membuktikan bahwa pembelajaran dengan model learning cycle lebih efektif digunakan daripada model konvensional terhadap kemampuan menulis teks deskripsi.

Berdasarkan hasil penelitian dapat diketahui bahwa terdapat pengaruh yang signifikan pada penggunaan model learning cycle terhadap kemampuan menulis teks deskripsi siswa kelas VII SMP Negeri 2 Nainggolan Tahun Pembelajaran 2019/2020. Pada pembelajaran yang berlangsung di kelas kontrol, keaktifan siswa dalam pembelajaran di kelas masih rendah. Siswa masih sebagai pendengar dan pelaksana tugas yang telah diberikan oleh guru. Adapun hasil penelitian yang telah dilaksanakan kepada 30 sampel dengan nilai paling rendah yaitu 33, nilai paling tinggi yaitu 83 dengan rata-rata 65,2, standar deviasi 15,48, dan standar error 2,78. Adapun strutur teks deskripsi dengan skor 3 adalah sebanyak 9 orang atau 28,125\%, skor 2 sebanyak 16 orang atau $50 \%$, dan skor 1 sebanyak 7 orang atau 21,875\%. Sedangkan ciri kebahasaan dengan skor 3 sebanyak 5 orang atau $15,625 \%$, skor 2 sebanyak 26 orang atau $81,25 \%$ dan skor 1 sebanyak 1 orang atau 3,125\%. Sedangkan frekuensi penilaian berada pada kategori baik sekali sebanyak 0 orang atau 0\%, kategori baik sebanyak 10 orang atau $31,25 \%$, kategori cukup sebanyak 13 orang atau 40,62\%, kategori kurang sebanyak 6 orang atau 18,75\% dan kategori sangat kurang sebanyak 3 orang atau $9,37 \%$.

Berdasarkan pedoman silabus dan kriteria ketuntasan minimal (KKM) yang ditetapkan yakni 70, maka siswa dianggap belum mampu / belum tuntas dalam menulis teks deskripsi. 
Sementara dalam pembelajaran di kelas eksperimen dengan menggunakan model learning cycle, siswa aktif dalam pembelajaran dengan interaksi yang hidup antara guru dan siswa serta siswa dengan siswa. Selain itu model tersebut juga berhasil membangun sifat kerjasama antar siswa serta keaktifan siswa dalam mendapatkan informasi yang berbeda pada saat yang bersamaan. Adapun hasil penelitian yang telah dilaksanakan kepada 32 sampel dengan nilai paling rendah yaitu 50, nilai paling tinggi yaitu 100 dengan nilai rata-rata 77,18 , standar deviasi 10,84, dan standar error 1,88. Adapun struktur teks deskripsi dengan skor 3 sebanyak 19 orang atau 59,375\%, skor 2 sebanyak 13 orang atau 40,625\%. Sedangkan ciri kebahasaan dengan skor 3 sebanyak 3 orang atau 9,375\%, skor 2 sebanyak 28 orang atau $87,5 \%$, skor 1 sebanyak 1 orang atau $3,125 \%$. Berdasarkan frekuensi penilaian di atas, jumlah siswa masuk dalam kategori baik sekali yaitu sebanyak 2 orang atau 6,25\%, kategori baik sebanyak 18 orang atau $56,25 \%$, kategori cukup sebanyak 11 orang atau 34,375\% dan kategori kurang sebanyak 1 orang atau 3,125\%. Berdasarkan pedoman silabus dan KKM yang ditetapkan yaitu 70, siswa sudah me lampaui hasil yang diharapkan / tuntas.

Berdasarkan perhitungan hasil penelitian diperoleh nilai rata-rata post test kelas eksperimen $(77,18)$ lebih tinggi daripada nilai rata-rata pre-test kelas kontrol $(65,2)$. Adapun skor pada struktur dan ciri kebahasaan kelas eksperimen meningkat dari kelas kontrol. Selanjutnya pada kategori nilai yang diperoleh dari nilai kelas kontrol dan kelas eksperimen terlihat bahwa nilai post test lebih tinggi. Hal tersebut dapat dilihat dari kategori nilai sangat baik, cukup, kurang dan sangat kurang dari masing-masing kelas. Peningkatan nilai tersebut diperoleh karena siswa lebih termotivasi setelah diterapkannya model learning cycle. Model learning cycle tersebut memicu keaktifan siswa baik dalam menerima maupun memberi informasi, sehingga mengubah siswa pasif menjadi aktif. Model learning cycle dapat dijadikan alternatif pembe lajaran bagi guru dan pengetahuan bagi siswa serta dapat membangun kerja sama antar siswa untuk berfikir kritis dalam berbagi informasi dengan singkat dan teratur sehingga dapat mempengaruhi kemampuan siswa dalam menulis teks deskripsi (Istarani, 2017:129). 
Berdasarkan uraian di atas, dapat dikatakan bahwa model learning cycle lebih efektif digunakan pada pembelajaran menulis teks deskripsi. Hal ini terbukti pada hipotesis penelitian bahwa $t_{o}$ yang diperoleh lebih besar dari $t_{\text {tabel }}$ yaitu $3,576>2,03$. Karena $t_{o}$ yang diperoleh lebih besar dari $t_{\text {tabel }}$, maka dapat dinyatakan $H_{o}$ ditolak dan $H_{a}$ diterima. Hal ini me mbuktikan bahwa pembelajaran dengan model learning cycle lebih efektif digunakan daripada model konvensional terhadap kemampuan menulis teks deskripsi

\section{E. KESIMPULAN}

Berdasarkan hasil penelitian dan pembahasan yang telah diuraikan pada bab sebelumnya, maka dapat disimpulkan beberapa hal yaitu Kemampuan menulis teks deskripsi siswa kelas VII SMP Negeri 2 Nainggolan Tahun Pembelajaran 2019/2020 dengan model konvensional nilai post tes terendah 33, tertinggi 83, nilai rata-rata 65,2, standar deviasi 15,48, dan standar error 2,78. Kemampuan menulis teks deskripsi siswa kelas VII SMP Negeri 2 Tahun Pembelajaran 2019/2020 dengan model learning cycle nilai terendah 50, nilai tertinggi 100 , nilai rata-rata 77,18, standar deviasi 10,84 , dan standar error 1,88 . Model learning cycle lebih efektif digunakan daripada model konvensional terhadap kemampuan menulis teks deskripsi siswa kelas VII SMP Negeri 2 Nainggolan Tahun Pembelajaran 2019/2020. Hal ini dapat dibuktikan pada hipotesis penelitian bahwa $t_{o}$ yang diperoleh lebih besar dari $t_{\text {tabel }}$ yaitu 3,576> 2,03. Karena $t_{o}$ yang diperoleh lebih besar dari $t_{\text {tabel }}$, maka dapat dinyatakan $H_{o}$ ditolak dan $H_{a}$ diterima.

\section{F. SARAN}

Berdasarkan kesimpulan di atas, maka sebagai tindak lanjut penelitian ini dikemukakan saran-saran sebagai berikut. Berdasarkan hasil penelitian, model learning cycle efektif terhadap kemampuan siswa menulis teks deskripsi. Oleh Karena itu, model ini dapat dijadikan sebagai salah satu elsternatif pembelajaran dalam proses belajar mengajar di kelas. Penerapan model learning cycle di dalam proses pembelajaran, diperlukan pemahaman guru yang lebih baik lagi, baik dari 
segi persiapan, alokasi waktu, pelaksanaan hingga evaluasi agar harapan untuk meningkatkan kemampuan siswa dalam menulis teks deskripsi tercapai. Bagi peneliti, selanjutnya disarankan agar tetap memperhatikan perkembangan model pembelajaran yang efektif, inovatif dan menarik sehingga dapat lebih meningkatkan kemampuan siswa dalam menulis teks deskripsi.

\section{DAFTAR PUSTAKA}

Akhadiah, Sabarti. 1993. Bahasa Indonesia III. Jakarta. Proyek Pembinaan Tenaga Kependidikan. Departemen Pendidikan Dan Kebudayaan.

Made, Wena. 2009. Strategi Pembelajaran Inovatif Kontemporer. Suatu Tinjauan Konseptual Operasional. Jakarta: PT. Bumi Aksara.

Tarigan, Henry Guntur. 2008. Menulis sebagai Suatu Keterampilan Berbahasa. (Edisi Revisi). Bandung: Angkasa.

Sayuti, Suminto A. 2009. Modul Menulis Fiksi. Yogyakarta: PBSI FBS UNY.

Dian,Permanasari. 2017. Kemampuan Menulis Teks Deskripsi Siswa Kelas VII SMP Negeri 1 Sumber Jaya Lampung Barat. Jurnal Pesona. Volume 3 No. 2: $156-162$.

Erwansyah . 2014. “ Kemampuan Menulis Paragraf Deskriptif Siswa Kelas VII C SMP Negeri 17 Batanghari Tahun Ajaran 2013/2014.

Siburian. 2010. Efektivitas Teknik Clustering 'Pengelompokan' terhadap Peningkatan Kemampuan Menulis Karangan Deskripsi Siswa Kelas X SMA Negeri 1 Lintongnihuta Tahun Pembelajaran 2009/2010. Skripsi pada FBS UNIMED: tidak diterbitkan.

Puspita, Vera. 2013. Skripsi: Pengaruh Penerapan Model Learning Cycle Terhadap Kemampuan Menulis Paragraf Deskripsi Pada Siswa Kelas X SMA Prayatna Medan Tahun Pembelajaran 2012/2013. http://www.pdf4free.com. Diakses 15 Februari 2019. 